\title{
"These are cases which it is inadvisable to drag into the light of day" : Disinterring the Crime of Incest in Early Twentieth-Century England
}

\section{Kim Stevenson}

\section{(2) OpenEdition \\ Journals}

Electronic version

URL: http://journals.openedition.org/chs/1669

DOI: 10.4000/chs.1669

ISSN: 1663-4837

Publisher

Librairie Droz

\section{Printed version}

Date of publication: 1 December 2016

ISBN: 978-2-600-01953-8

ISSN: $1422-0857$

\section{Electronic reference}

Kim Stevenson, " "These are cases which it is inadvisable to drag into the light of day" : Disinterring the Crime of Incest in Early Twentieth-Century England ", Crime, Histoire \& Sociétés / Crime, History \& Societies [Online], Vol. 20, n² | 2016, Online since 01 December 2018, connection on 30 April 2019. URL : http://journals.openedition.org/chs/1669; DOI : 10.4000/chs.1669

\section{This text was automatically generated on 30 April 2019}

(C) Droz 


\title{
"These are cases which it is inadvisable to drag into the light of day" : Disinterring the Crime of Incest in Early Twentieth-Century England
}

\author{
Kim Stevenson
}

\section{Introduction}

1 The historiography of late twentieth century child sex offending in England and Wales is still being uncovered and written; most recently in light of the unprecedented disclosure of cases of historic sexual abuse revealed by the Savile Inquiry and Goddard's Independent Child Sexual Abuse Inquiry into institutional abuse. ${ }^{1}$ While the current revelations of sexual abuse over the last half century are unparalleled, at least the unrelenting publication of media reports, commentaries and prosecutions will provide an accessible and significant archive for future academic analysis. In stark contrast, the historiography relating to child sexual exploitation including incestuous relations with children during the first half of the twentieth century is much more limited. With specific reference to the crime of incest, there has been significant academic critique of the late nineteenth century debates and social discourse associated with the arguments for and against criminalization and the subsequent enactment of the Punishment of Incest Act 1908. But for the early twentieth century, and especially post-1908, there are significant chronological gaps in the literature in respect of child sexual abuse generally, and more specifically, the impact and wider socio-legal and cultural context of the implementation of the incest statute.

2 This hiatus is bookended by Jackson's seminal work Child Sexual Abuse in Victorian England and resumed by sociologist David Finkelhor's extensive contemporary studies of the 
phenomenon from the 1970s to the present day. ${ }^{2}$ In between, Smart provides a useful overview of how, from 1910 to 1960 , child sexual abuse was perceived and understood as a form of harm, but confirms that it is a much neglected period as regards more detailed scholarship. ${ }^{3}$ One explanatory factor for this dearth of commentary is the apparent scarcity of accessible and reliable archival material detailing prosecutions of sexual offences committed against children including official court reports and, compared to the wealth of crime reportage published in the nineteenth century, newspaper coverage. Currently, Louise Jackson and Adrian Bingham are working on an ESRC funded research project to identify the underlying reasons for this as part of mapping and analysing the social, legal and political responses to child sexual exploitation since the 1920s. ${ }^{4}$ Predictably initial findings confirm that after 1918 newspaper reporting of child sexual abuse generally was very brief : "Reporting was episodic and fatalistic, as if these crimes were an inevitable feature of society" ${ }^{\prime \prime}$ or at least sections of it. This is despite the fact that compared to the crime of incest there were no definitive legislative restrictions on the public reporting of institutional or non-familial abuse. In contrast, the Punishment of Incest Act 1908 which made incestuous activities with children or between consenting adults a secular offence for the first time, included a prohibition that made it unlawful for the press to report such prosecutions. From the legal perspective at least, it can therefore be argued that any explanatory factors as to the invisibility of newspaper reportage of non-incestuous cases of child sexual exploitation may differ from those elucidating the reasons for any similarly constrained reporting of incest prosecutions, because of the probability that these are more likely to be undetectable due to the reporting ban imposed for the moral protection of society in general.

3 This article aims to add new material to the debate by, somewhat counterintuitively, analysing the public and legal discourse concerning the 'silences' surrounding the prohibition on the reporting of the prosecution of incest cases heard in camera in the English criminal courts between 1908 and 1922. As will be demonstrated, an informative amount of source material can be gleaned from synthesizing newspaper reports and comment with the official law reports of criminal appeals against convictions for incest to enhance understandings of how the Act was applied and cases proceeded with. It charts the legal debates regarding the need for privacy, as underlined in the title quote from the Lord Chancellor, the Earl of Halsbury, Harding Giffard. Halsbury believed that the subject was too repulsive for public debate and expressed considerable resistance to the proposed Bills opining that for two reasons the crime of incest should not be "brought into the light of day". First, the issue would be greatly magnified if prosecuted through the public arena of the criminal courts, and second he believed that the newspaper press could not be trusted to report such cases responsibly. Halsbury eventually secured an amendment that any prosecution for incest would require the consent of the Director of Public Prosecutions, and any subsequent criminal trial must be held in camera in a closed court, thereby excluding the public and effectively repressing any media publication of the case.

The discussion interrogates the extent to which Halsbury's pre-emptive criticisms were justified in respect of charges of incest against children suggesting that as cases started to be prosecuted in the courts, it was not only the press, but also judges and magistrates who expressed disquiet about such censure. The article focusses on one judge in particular, Mr Justice Darling, who, based on his experience as a trial judge who had heard numerous indictments of sexual assault and a representative number of incest 
cases, became the leading protagonist in urging that the in camera rule be repealed and whose criticisms would ultimately contribute towards a resolution of the issue.

\section{Addressing the Apparent Paucity of Source Material}

5 Undeniably, the revelation of incestuous relationships amongst the urban poor by the Victorian social explorers, child crusaders and moral campaigners including Mearns, Shaftesbury and Booth did much to educate the public and bring incest "into the light of day" precipitating the eventual passage of the 1908 Act. Social historians, notably Behlmer, Hendrick, and Wohl, ${ }^{6}$ first correlated this public disclosure of incest and its subsequent criminalization in the 1908 Act complemented by Jeffrey's feminist perspective of the role of moral and child welfare campaigners and Jackson's study on the contemporaneous prosecution of familial sexual assaults. ${ }^{7}$ Bailey, a legal historian, has tracked the legislative process of the 1899-1907 Bills in his definitive account published in 1979. ${ }^{8}$ This has been further contextualised by Bell's analysis of how the parliamentary debates constructed the crime of incest. Adopting a feminist informed critique to challenge Foucauldian theory, she examines how the conflicting proposals for criminalisation coalesced around three key themes : health and inbreeding, causation of harm, and threat to the institution of the family. ${ }^{9}$ It is not within the scope of this article (nor is there the space) to revisit the debates about whether the legislation was intended to be a protectionist measure or to assuage public and medical concerns about the genetic dangers associated with incestuous unions and eugenics arguments as these have been expertly covered by Wolfram. ${ }^{10}$ Similarly, Bates' recent work examining the role and perspectives of medical experts - including sexologists and psychiatrists - and medical testimony and evidence in relation to the prosecution of sexual offences more generally usefully incorporates the key aspects of medical jurisprudence. ${ }^{11}$ The aim here is to focus on the post-Act discourse as, despite such compelling work, there has been little critique of the immediate impact of the legislation and repercussions associated with the reporting prohibition. This paper therefore examines the judicial, legal and media responses to the criminalization of incest and in particular the reporting ban as it was these institutions that the provision most directly affected.

Olafson et.al. offer a broad and comprehensive interdisciplinary survey of the literature concerning the modern history of child sexual abuse but this is primarily from a definitional and psychiatric perspective and does not specifically review incestuous abuse. They endorse the fact that, despite the efforts of the early twentieth century child welfare campaigners and feminists, child sexual abuse was repeatedly repressed, creating a "long history of cultural denial" that remained unchallenged until the domestic violence campaigns of the 1970s exposed the phenomenon of child sexual abuse as materializing from the more generic categorization of physical child abuse. ${ }^{12}$ Within this manifestation the secrecy of the incest 'taboo' and cultural reluctance to talk about such a sensitive subject was darkly concealed making access to reliable historical sources even more problematic. La Fontaine stresses that "empirically there is considerable overlap between incest and the sexual abuse of children, but the former is not a sub-category of the latter." ${ }^{13}$ Mitterauer cautions that the concept of the incest taboo is primarily an "academic construct" and one that should be dismissed as it "tends to obscure the fundamental difference between the abhorrence of incest as an aspect of behaviour and the prohibition of incest as a social rule. ${ }^{14}$ However, as Davidoff et.al. remind us, incest 
was one of the family secrets most silenced in family life narratives during this period making it "almost impossible to uncover historically because its existence has been denied within most families and communities." ${ }^{15}$ Cohen challenges this somewhat suggesting that the Victorians regarded incest more matter-of-factly because of the problem of overcrowded housing and that the existence of such secrets generally was a necessary precursor to the subsequent development of modern family privacy ${ }^{16}$ But post-1908 the deliberate legal withdrawal of incest prosecutions from the public domain inevitably generated a greater reticence and reluctance to disclose and discuss such 'secrets' even behind closed doors. Thus in the context of this article it needs to be acknowledged that any restrictions on reporting incestuous acts (by judicial discretion pre-1908 and by legislation post-1908) will not only have intensified any such social taboos, but expressly and implicitly contaminated official information and responses relating to the prosecution of incestuous behaviour. It is therefore acknowledged from the outset that there are significant practical difficulties in undertaking qualitative - and even more problematically quantitative - historiographic research into the prosecution of child sex offences due to the official censure, which began from the early nineteenth century onwards, of court reports (including the old Bailey Sessions Papers) on the grounds of immorality as confirmed by Clark, Jackson, and Wiener, amongst others. ${ }^{17}$

Consequently, as I have previously argued, the most accessible and reasonably accurate source for analysing the prosecution of sexual crimes between the 1850s and 1914 are the newspaper court reports, written by lawyer-reporters, of cases heard in the Assizes, police courts and magistrates' courts such as those published in The Times. ${ }^{18}$ Trainee and qualified barristers, commissioned by editors and proprietors, listened to and transcribed cases on a daily basis to reproduce a contemporaneous narrative of the proceedings. Writing anonymously protected their legal integrity as did the selection by the editor of the reports to be published..$^{19}$ However, as reiterated in more detail below, reports of incestuous behaviour are inevitably rare or disguised in the reportage, not only because the press were constrained by public sensibilities, but primarily because incest was not yet a crime; fathers who sexually abused their daughters were either charged with rape or attempted rape, provided there was sufficient evidence of non-consent, carnal knowledge under the age of consent where the girl was below marriageable age, or sexual assault.

Once incest was criminalised in 1908, the press were further constrained as the Act specifically prohibited the publication of any criminal proceedings relating to any charge or prosecution. Yet intriguingly, despite the ban, examples of press reports and commentary can be found, particularly in The Times, albeit in insufficient numbers on which to base any scientific analysis. The fact that these cases were selected for publication strongly suggests that they were thought to be of some particular or distinct interest to the readership. Typically, such exemplars highlight a specific legal issue or concern raised by the judge or trial lawyers relating to the enforcement of the new Act, such as, somewhat ironically, whether or not the case itself could legally be reported in the press given the 1908 Act's censure on publication.

9 This is an important revelation in terms of source material as the early decades of the twentieth century witnessed a significant reduction in the number of press reports in both national and local papers of rape and child sex offences despite an apparent increase in the number of offences prosecuted. ${ }^{20}$ The reasons for this have not yet been fully established but possible factors include a combination of Edwardian propriety, moral 
vigilantism and the new tabloid journalism with its emphasis on sport and entertainment. Similarly, as lawyer-reporters started to be replaced by crime journalists, there was a corresponding diminution in the amount of detail-rich crime reportage published in the quality press. The Times, however, did retain its lawyer-reporters, thus I would posit that their interest in the legal nuances and implications of the cases reviewed confirms that the reports must have been written by someone who understands the law and has the requisite legal knowledge and training to convey the judge's reasoning and lawyers' emphasis to both professional and lay audiences. I would therefore defend the examples referenced here as a valuable and reliable insight into how crimes of incest were actually dealt with.

\section{Criminal Offence or Immoral Outrage ? Setting the Contextual Framework}

10 Historically, the question of whether incest was prohibited as a serious violation against the person, or tolerated as a consensual but immoral act between adults, was mainly one that fell under the jurisdiction of the church rather than the state. ${ }^{21}$ Incest was made a criminal offence in Scotland in 1567 punishable by death, ${ }^{22}$ but in England escaped criminalisation under Elizabeth's Act of 1576, which aligned the age of sexual protection with the age of marriage at twelve years. ${ }^{23}$ From 1835 incest was removed from the direct jurisdiction of the ecclesiastical courts when Lord Lyndhurst's controversial Deceased's Wife's Sister's Act made all marriages within the prohibited degrees of affinity and consanguinity void. ${ }^{24}$ As Clark and Conley concede from their examination of earlynineteenth-century newspaper reports and Kent criminal court records respectively, reported examples of fathers sexually assaulting or having carnal knowledge with their daughters were comparatively rare. According to Clark, only 25 percent of all sexual assaults known to the authorities were reported in the press. From her sample of 138 cases of sexual assault committed against girls under thirteen published in London newspapers from 1800-1845, eighteen involved incestuous acts with a further thirteen examples involving girls of marriageable age at twelve years and above. ${ }^{25}$ She also asserts that men so charged often believed they had not committed any crime at all (fathers had absolute custody of their children until 1839), something that Justice Darling would later emphasise as an unanticipated consequence of the ban on reporting incest cases. ${ }^{26}$ As D' Cruze points out, it would have been incumbent on the court to take over the patriarchal role of the father in which case the mother's respectability was often as important as the child's. ${ }^{27}$ However, the majority of fathers were acquitted, either on the grounds that the girl failed to show physical resistance or because she had 'permitted' her father to have sexual intercourse on a regular basis implying that it must have been with her consent. ${ }^{28}$

11 Despite such ambiguities, in private, the Victorian and Edwardian public officially disapproved of father-daughter incest as Pollock confirms: "law and society condemned child abuse long before the Prevention of Cruelty Act 1889" evidencing 385 reported cases of child abuse and neglect reported in The Times from 1785 to 1860, which included nineteen recorded cases of incestuous relations mainly prosecuted as sexual assaults. ${ }^{29}$ This would have included examples from the 1850s such as John Ayscough transported for life for the rape of his sixteen year-old daughter and John Rowe, sentenced to fifteen years penal servitude for raping his nine year-old daughter, demonstrating that sentences were severe. ${ }^{30}$ But familial abuse was unequivocally too sensitive a subject to 
broadcast. Clark cites a magistrate in 1827 whose justification of a lenient sentence echoes Halsbury's title comment : "'it would be better perhaps, though the monster ought not to go unpunished, that the public feeling should not be wounded by the disgusting details" necessarily exposed in the trial. ${ }^{31}$ Such inherent reluctance to publish the intimate details of the case is understandable, especially in the context of the masculine domination of the courtroom and legal process overlain by the stereotypically gendered expectations of and conformity with the respectability imperative..$^{32}$ It may also be perceived as an official endorsement of the so-called incest 'taboo', burying the issue even deeper into both the private and public consciousness.

Incontestably the Victorians were cognizant of the fact of incest, but as Houghton asserts, "they refused to look at life candidly. They shut their eyes to whatever was ugly or unpleasant and pretended it didn't exist. Conformity, moral pretension, and evasion those are the hallmarks of Victorian hypocrisy." ${ }^{13}$ Hendrick affirms that it was an issue they were unwilling to confront, largely because "the potentially destructive truth about human propensity to sexual abuse would have created unbearable contradictions in the logic of the [bourgeois domestic] ideal." ${ }^{34}$ Wohl adds that there remained an overriding public conspiracy of silence reaching 'Watergate proportions' where the word 'incest' was hardly ever used in favour of the more euphemistic 'unnatural practices', 'vice' and 'promiscuous herding'. ${ }^{35}$

13 Such assertions need to be considered in light of the increasing acknowledgement and formulation of the social construct of childhood, classified by Hendricks as a chronological series of consecutive and distinguishable stages - sometimes legally defined - delineated by age, intellectual capacity and cultural context. ${ }^{36}$ Children needed to be treated as children, not adults, but as Hoyles points out, such distinction inevitably disclosed the potential for abuse : as the Victorians accepted "the life of childhood, they also uncovered childhood sexuality". ${ }^{37}$ At the forefront was the 'delinquent female' bearing the irreconcilable distinction of expected innocence but who, through familial sexual exploitation, had lost her reputation and was now regarded as 'experienced' and 'precocious'. Jackson presents a number of cases in illustration confirming that in court such child witnesses had to "prove their integrity as "witnesses of the truth" demonstrating that they were not delinquent and that questions about whether they were "victims or threats, morally innocent or guilty of delinquency, affected the way they were dealt with in the witness box." ${ }^{38}$ But in Scotland where incest was criminalized, such 'delinquency' could be harshly punished as in the example of Mary Gray, 'a girl', was sentenced to transportation for life for committing incest with her father Daniel Gray. ${ }^{39}$

South of the border, however, child reformers, purity movements and feminist campaigners demanded equivalent legal and also social reform though not all had the same motive. Weeks speculates that "the social-purity agitation over incest reflected middle class anxieties and tensions concerning the sanctity of family life rather than objective reality of working class conditions." ${ }^{40}$ In 1871 Shaftesbury pre-emptively wrote that, "The evils ...are enormous and indisputable, but they are of so private, internal and domestic a character as to be beyond the reach of legislation." ${ }^{11}$ Booth disclosed that "Incest is so familiar as to hardly call for remark" 42 and opined that, "when unearthed it was a crime sufficiently gross to incite a momentary horror, yet, ironically, never so rare as to sustain a long-lived campaign for reform." ${ }^{43}$ Such revelations were confirmed by evidence presented by witnesses to the Royal Commission on the Housing of the Working Classes 1884-1885 which concluded that overcrowding and the single room resulted in 
immorality and incest. ${ }^{44}$ Jackson cautions that there was a significant divergence of opinion over the veracity of such claims and that some cases were dealt with informally by the local community in preference to seeking criminal sanctions. ${ }^{45}$

Meanwhile, the feminist campaigner, Ellice Hopkins, an early supporter of the Criminal Law Amendment Bills 1881-1885, gave evidence to the House of Lords Select Committee on the Protection of Young Girls 1881 about the need to raise the age of sexual protection to sixteen years. Through her Ladies Association for Friendless Girls she spent two years increasing awareness about the potential link between incest and child prostitution. ${ }^{46}$ Further supporting the need for legal reform, in 1883 W.T. Stead helped publicize Mearns' 'Bitter Cry of Outcast London' in the Pall Mall Gazette with its searing descriptions of the misery of those living in the London slums and references to immoral incestuous relations. ${ }^{47}$ Together with Shaftesbury's London Society for the Prevention of Cruelty to Children, he campaigned for the criminalization of incestuous conduct with young girls. In its first year of operation the SPCC (later the NSPCC) received 12 referrals concerning "an evil which is altogether unmentionable" alluding to cases of sexual assault and incest. ${ }^{48}$ Despite hostile opposition in the House of Lords (some Peers were concerned that it was they who needed protection from the sexual advances of young females) Parliament agreed to increase the age of sexual protection to sixteen years but refused to consider criminalizing incest. ${ }^{49}$ The Criminal Law Amendment Act 1885, passed just a few days after Stead published his own scandalous exposé, The Maiden Tribute, in July 1885, made carnal knowledge with a girl under sixteen years punishable as a misdemeanour (section 5) and under thirteen years as a felony (section 4).

The NSPCC and other prosecutory bodies such as the National Vigilance Association (NVA) used these provisions to prosecute cases of incestuous activity against girls under sixteen sharing evidence with the police and others to secure convictions. But in imposing a three month prosecution limit from the date of the offence in respect of section 5, the Act was largely unusable for cases of incest unless complainants reported any abusive activity immediately as historic offences could not be charged. This precipitated considerable pressure on the Home Office from certain Poor Law Unions and the NVA to extend it to twelve months. ${ }^{50}$ As Mort notes, increasing concern about the difficulties of prosecuting incest "pointed up the growing convergence of opinion" between social purists, women's groups, the police and the Home Office. ${ }^{51}$ The NSPCC and the NVA pressed for further reform of the 1885 Act to make incest a specific crime, but proposed amendments in 1893, 1894 and 1896 all failed, largely because of disagreements in Parliament over other clauses. In 1899, with support from the majority of chief constables, the first Incest Bill was introduced but this too was lost. ${ }^{52}$ Colonel Amelius Lockwood, Conservative MP and Parliamentary spokesman for the NVA, took charge sponsoring two more Private Members Bills in 1903 and 1907, but these also met considerable resistance in both Houses. Lord Alverstone had included an incest clause in the Prevention of Cruelty to Children Bill 1903 "as a consequence of representations made to me by grand juries in the North of England", but withdrew it when he realised its opposition was likely to destroy the whole Bill. ${ }^{33}$ Concerns were expressed about a Private Member's Bill making a hitherto moral transgression a crime, ${ }^{54}$ the likelihood of prosecutions multiplying at the Assizes, the potential for blackmail (especially against gentlemen), a failure to recognize any defence of 'consent', and that education was thought more appropriate than criminalization. It is important to note that incest was perceived as largely a matter practised by adults (typically siblings) living in cramped 
conditions ; there was little acknowledgement of the risk to children except, as Herbert Samuel, Under-Secretary at the Home Office. pointed out, where born from an incestuous connection. ${ }^{55}$

Bell presents a useful discourse analysis of these debates showing how incest ultimately became constructed and 'problematized' as a specific crime and how the clashes over this "object of thought" between medical, social welfare, feminist and legal perspectives meant that "the parameters of what constitutes the 'truth' about incest are continually attacked and reconstituted. ${ }^{156}$ Halsbury, was particularly vociferous ; strongly believing that this unpalatable subject would be magnified if prosecuted through the criminal courts :

I regret very much that the nature of this Bill is one which renders it repulsive to everybody to discuss it.... legislation of this character is calculated to do an infinite amount of mischief... these are cases which it is inadvisable to drag into the light of day. ${ }^{57}$

He was especially concerned about the 'mischief' that the Press might cause if allowed to report cases with impunity. Earl Donoughmore, who sponsored the Bill in the Lords, dismissed such fears: "I do not believe that as a result of its passing, the halfpenny newspapers would endeavour to make fortunes by spreading detailed reports of criminal cases under this Bill." Halsbury responded :

The noble Earl says he is confident that certain newspapers will not make capital out of these cases. I do not know where his confidence comes from. It strikes me that anything of this sort would be eagerly grasped by some portion of the Press, who make these things more public than they otherwise would be. ${ }^{58}$

The 1903 Bill was lost, "foundered", as Wolfram concludes, "on the rock of affinity" as the emphasis shifted more towards prohibiting consanguinity with its perceived genetic dangers. ${ }^{59}$ Reintroduced in the Lords in 1907 the Bishop of St Albans took over its sponsorship informing the House that during the preceding year 42 cases of incestuous conduct with girls had been referred to the NSPCC, Birmingham reported eleven cases, Liverpool twelve and the Metropolitan Police 36. Additionally, of the 193 petitions received by the Home Office pleading remission in sentence for a conviction of rape or carnal knowledge of a girl under sixteen years, 51 concerned incestuous convictions. ${ }^{60}$

This time the Lords were convinced of the need for reform and the Incest Bill was passed, but Earl Russell reminded them, and the new Lord Chancellor Loreburn, of Halsbury's earlier disquiet. Russell proposed that prosecutions require the consent of either the Attorney General or the Director of Public Prosecutions, and more significantly, that all proceedings be held in camera encapsulated in section 5 of the Punishment of Incest Act. The press and the public were to be prohibited from attending any incest trial and the press from publishing anything about the criminal proceedings, including the simple fact that a person had been indicted, acquitted or convicted. The ban, secured by the Liberal Earl Beauchamp (William Lygon), was something he would later come to regret. It is suggested that Hendrick somewhat misses the point when he claims that because of "the sparsity of reported cases of incest, the Act was 'symbolic' of public and legal disapproval rather than an effective instrument of law." ${ }^{11}$ 


\section{Bringing Incest into the 'Light' of Day?}

21 Given its controversial and contested nature the 1908 Act was relatively well crafted. But as Wolfram notes, what was "almost revolutionary", given the permissible combination of legal marriage within consanguineous and affinal relations (except of course for the deceased's wife's sister as mentioned above), "was the narrow range of relatives included." ${ }^{62}$ Intercourse between first and second blood relatives, as with marriage, became a criminal offence, but in effect was legitimised for "close kin" who could not marry due to affinal relations or because they were third degree blood relatives. Section 1 prohibited, in the case of a man, carnal knowledge with anyone who to his knowledge is his grand-daughter, daughter, sister or mother, punishable with between three and seven years penal servitude, two years or less with or without hard labour, or life imprisonment if the girl was under thirteen. Section 2 provided that where a female aged sixteen years or over permits a man she knows to be her grandfather, brother, son or father to have carnal knowledge with her by her consent she also commits an offence. The penalty is identical to section 1 but without life imprisonment where the male victim is under thirteen. The age thresholds matched the ages of protection established in the Criminal Law Amendment Act 1885. The 'permissive' aspect was deliberately gender biased, as it was known that most cases involved fathers coercing their daughters, who had little choice but to 'accede' to their father's demands. The imposition of culpability for females over sixteen years is therefore more related to the disapproval of sibling incest despite the fact that both parties "are equal in kinship terms and mutual consent is implied."63

The two offences are unusual from another gender perspective; this was the only crime (until the Sexual offences Act 2003) that expressly protected boys under sixteen years from coerced sexual intercourse, albeit limited to a heterosexual context. There are no reports of any such prosecutions within this period probably because there was an irrebuttable presumption in law (not abolished until the Sexual Offences Act 1993), that boys under fourteen were physically incapable of sexual intercourse, combined with the practical impossibility of making any such allegation. Nor was it unlawful for a grandmother to have carnal knowledge with her grandson, as it was thought there was little risk because she would be beyond child-bearing age. Prosecutions required the consent of the Director of Public Prosecutions, but heeding the criticism about the three month time limit imposed in the CLAA 1885, no such restrictions were made in respect of incest prosecutions.

An examination of the annual criminal statistics and returns gives some indication of the impact of the new legislation in terms of prosecutorial decisions. Predictably, the numbers are small ; in the first five years after the Act was passed, an annual average of 56 incest offences was recorded by the police in England and Wales of which 88 percent were prosecuted. Reflecting on the prosecution of incest from 1909-1923 the Departmental Committee on Sexual Offences against Young Persons 1924-1925 acknowledged that "It is readily admitted by official and other witnesses that the number of incest cases reported to the police can only be a small proportion of those that actually occur" and that where penetration could not be proved alternative charges of indecent assault were substituted and the case heard summarily by the magistrates. ${ }^{64}$

Throughout the twentieth century the number of annual prosecutions remained small (between 100 and 200 cases) but, as Soothill and Gibbens found in their research on 
recidivism rates from the 1950s to the 1970s, typically only 50 percent of the number of cases known to the police were prosecuted, this figure remained consistent despite population increases ${ }^{65}$ In the 1980 s, the Criminal Law Revision Committee undertook a review of the 1908 Act and recommended that the word 'incest' be 'redacted' from the law and replaced with more broadly termed offences of 'unlawful familial intercourse', but these were not approved.$^{66}$ Criminal law barrister James Morton highlighted a 1988 case where a brother and sister who had grown up independently were prosecuted but received an absolute discharge from a sympathetic judge. He asserted that the legislation was "no longer relevant" and unfairly criminalized consensual activities between adult siblings. ${ }^{67}$ There was an increasing averseness to using the term generally. In 1987184 males were proceeded against for incest, but this dropped to just 25 by 1997, suggesting that the legislation and associated stigma of being convicted of incest had finally run its course. ${ }^{68}$ Thus the statistical information presented below needs to be considered in the light of the contested debate about the criminalization of incest and the actuality that the true incidence of sexual abuse in the home will always be concealed.

Compared to the number of cases proceeded with to trial for defilement under section 5 (girl under sixteen years) and section 4 (girl under thirteen years) of the CLAA 1885, the annual average for the number of incest crimes reported and known to the police that were subsequently prosecuted was consistently high at around 87 percent as shown in Table 1. Exact comparisons are impossible as some defilement cases, especially pre-1908, would have included incestuous relations as would have some post-1908. Additionally incest cases were not segregated as to the age of the victim or relationship with the accused. ${ }^{69}$ While a minority of the latter may have involved victims over the age of sixteen years such as adult brothers and sisters, the severity of many of the sentences imposed, as illustrated in Table 2 below, supports the proposition that the vast majority involved daughters under the age of sixteen, suggesting that there was a strong will to bridge the 'justice gap' and prosecute such cases. For these reasons it is not feasible to compare conviction rates for incest with conviction rates for other sexual offences committed against children under sixteen years because of the lack of clarity in the statistical returns in relation to both the specific offences charged and the final decision and disposal. These tables should, therefore, be regarded purely for illustrative purposes.

Table 1 - Comparison of number of cases reported to the police and subsequent committal to trial 1895-1919

\begin{tabular}{|l|l|l|l|l|l|l|}
\hline Annual average & \multicolumn{2}{l|}{$\begin{array}{l}\text { defilement of girl } \\
\text { under 16 }\end{array}$} & \multicolumn{2}{l|}{$\begin{array}{l}\text { defilement of girl } \\
\text { under 13 }\end{array}$} & \multicolumn{2}{l|}{ Incest } \\
\hline & $\begin{array}{l}\text { crimes } \\
\text { reported }\end{array}$ & $\begin{array}{l}\text { proceeded } \\
\text { to trial }\end{array}$ & $\begin{array}{l}\text { crimes } \\
\text { reported }\end{array}$ & $\begin{array}{l}\text { proceeded } \\
\text { to trial }\end{array}$ & $\begin{array}{l}\text { crimes } \\
\text { reported }\end{array}$ & $\begin{array}{l}\text { proceeded } \\
\text { to trial }\end{array}$ \\
\hline $1895-1899$ & 173 & $127(73.4 \%)$ & 187 & $117(62.5 \%)$ & & \\
\hline $1900-1904$ & 110 & $97(88.1 \%)$ & 142 & $101(71.1 \%)$ & & \\
\hline $1905-1909$ & 181 & $127(70.1 \%)$ & 156 & $101(64.7 \%)$ & 24 & $21(87.5 \%)$ \\
\hline $1910-1914$ & 238 & $187(78.5 \%)$ & 129 & $77(59.6 \%)$ & 71 & $61(85.9 \%)$ \\
\hline
\end{tabular}




\begin{tabular}{|l|l|l|l|l|l|l|}
\hline $1915-1919$ & 138 & $98(71.1 \%)$ & 78 & $37(47.4 \%)$ & 57 & $50(87.7 \%)$ \\
\hline
\end{tabular}

In the first year, 1909, 58 applications to prosecute incest were made to the DPP of which 30 were accepted resulting in 21 convictions, eight acquittals, one case pending and one Bill ignored..$^{70}$ In 1910,114 applications were made to the DPP and similarly 58 were accepted, of those 56 were prosecuted leading to 36 convictions, eighteen acquittals, one pending and one process refused. ${ }^{71}$

Interestingly, express reference is made in the 1910 statistical return to the doubling of the number of incest reports and prosecutions one year after the Act came into force. ${ }^{72}$ Jeffrey's notes that the contemporary feminist, Frances Swiney, was less impressed viewing the Act as ineffective because ultimately it relied on the male bias of juries and magistrates. ${ }^{73}$ However, a breakdown of the cases heard that first year shows that the sentences imposed in many cases were severe as illustrated in Table 2.

Table 2 - Cases prosecuted under the Punishment of Incest Act 19081 Jan-31 Dec 1909

\begin{tabular}{|l|l|l|l|l|}
\hline Accused & Informant & Assize Court & Date of trial & Disposal \\
\hline Albert Davies & Commr of Police & CCC & 23 Mar. & 12 mths hl \\
\hline James Norris & CC Bolton & Manchester & 19 Apr. & 9 mths hl \\
\hline Thomas Solloway & NSPCC & Leeds & 3 July & 5 yrs \\
\hline Isaiah Jenkins & CC Glamorgan & Swansea & 23 July & 2 yrs \\
\hline Thomas Dyson & CC Huddersfield & Leeds & 3 July & 5 yrs \\
\hline Evan Jones & CC Glamorgan & Swansea & 26 July & 5 yrs \\
\hline Christopher Taverner & Commr of Police & CCC & Jun sess. & 7 yrs \\
\hline Anon \& another & CC Gloucester & Gloucester & 28 Oct. & Acquitted \\
\hline Ernest Denly & CC Glamorgan & Swansea & 26 July & 7 yrs \\
\hline Anon & CC York & York & 18 Nov. & Acquitted \\
\hline Henry McLaren & Commr of Police & CCC & Sept sess. & 3 yrs \\
\hline Arthur Chaplin & Private pros & Birmingham & 22 Nov. & 3 yrs \\
\hline Daniel Drain & Commr of Police & CCC & Oct sess. & 3 yrs \\
\hline Anon & Commr of Police & CcC & Oct sess. & Acquitted \\
\hline Anon & NSPCC & Worship St & Oct sess. & dismissed \\
\hline
\end{tabular}




\begin{tabular}{|l|l|l|l|l|}
\hline Anon & Private pros & Leeds & 27 Nov. & Acquitted \\
\hline William Trowbridge & NSPCC & CCC & Nov sess. & 12 mths \\
\hline William Hallett & CC Hull & York & 18 Nov. & 12 mths \\
\hline Anon & CC Hull & York & 16 Nov. & Acquitted \\
\hline Henry Hedges & NSPCC & Maidstone & 20 Nov. & 10 yrs \\
\hline Robert Matthews & NSPCC & Warwick & 17 Nov. & 3 yrs \\
\hline Edward Robinson & NSPCC & Lincoln & $15 \mathrm{Feb} 1910$ & 5 yrs \\
\hline Harry \& Ada Kenhard & NSPCC & Monmouth & $22 \mathrm{Feb.}$ & 18 \& 6 mths \\
\hline Anon & CC Cumberland & Carlisle & $26 \mathrm{Jan}$. & Acquitted \\
\hline John Bell & CC Newcastle & Newcastle & $16 \mathrm{Feb.}$ & 7 yrs \\
\hline Anon & NSPCC & Windsor & $10 \mathrm{Feb.}$ & Acquitted \\
\hline Anon & NSPCC & Windsor & $10 \mathrm{Feb.}$ & Acquitted \\
\hline John Smith & Devizes & $24 \mathrm{Feb}$. & 3 yrs \\
\hline
\end{tabular}

Of these first 29 prosecutions referred to the DPP, twenty resulted in convictions, eight were acquitted and one dismissed. Complainant details were not recorded but the disposals suggest that where a custodial sentence of three years or more was imposed it is likely that the offence was perpetrated against a child. Conversely, the lower eighteen and six month sentences imposed on Harry and Ada Kenhard suggest that they were consenting adult siblings with the latter sentence reflecting Ada 'permitting' Harry to have intercourse with her. The table also highlights the source of the complaint with predictably the NSPCC referring nine cases, two from unnamed private prosecutors and the rest from police forces across the country.

Inevitably, those convicted soon started to challenge the Act's application, especially as the Criminal Appeal Act 1907 created a new Court of Criminal Appeal (CCA) in response to public disquiet about a number of miscarriages of justice including those of Florence Maybrick and George Edjali. ${ }^{74}$ Such appeals were published in The Times as well as the official law reports as they were not caught by the in camera rule, while synthesizing the two sources can provide a more detailed account of the legal issue, the lawyer-reporters (cognizant of the censure) continued to avoid any explicit narrative of the actual offence. However, with careful interpretation, an amount of detail can be gleaned.

The first appeal against conviction was launched by Henry Hedges convicted at Maidstone Assizes where he was sentenced to 10 years imprisonment. The official law report does not identify the specific charge but denotes the keywords of the appeal as "rape-fresh complaint and corroboration evidence". Typically, prior to 1908, fathers who sexually violated their daughters were charged with rape, but as many victims 'acquiesced' it was often difficult to prove non-consent. Reading the report a number of clues indicate 
incest : the prosecutrix was Hedges' fifteen year-old daughter who testified that he had "forcible connexion" with her. Hedges' wife testified that on returning home at 6.00am one morning she was surprised to find her daughter in the matrimonial bedroom apparently nursing their baby, a doctor was summonsed who confirmed that the daughter's hymen was broken with injuries consistent with frequent sexual intercourse. Hedges, representing himself, denied culpability challenging the veracity of his daughter's testimony. Revealingly, there is a note from the Lord Chief Justice in brackets : "This appellant must have been convicted under the Incest Act." 75 The CCA dismissed Hedges' appeal holding that the conviction was safe as his daughter's evidence was corroborated by the doctor.

Interestingly, the first appeal from the new CCA to the House of Lords concerned a case highlighting the issue of sibling incest. In 1910, a nine bench panel including Halsbury and Lord Chancellor Loreburn, reversed the CCA's decision to quash the conviction of William and Edith Ball, married siblings who had been indicted for incestuous activities in July and September that year. Cross-referencing the law report with The Times' details of the original conviction reveals that Edith received six months imprisonment reflecting her apparent lesser culpability in 'permitting' her brother to have sexual intercourse with her, and William three years as the presumed instigator. ${ }^{76}$ Their sexual connexion is euphemistically expressed as "their guilty passion for each other" thereby sparing Halsbury's blushes and proven by the birth of their child in 1908 and consequent marriage, which the CCA was held to have wrongly considered inadmissible in relation to proving the indictment. ${ }^{77}$

The evidential difficulties of proving incest and the additional requirement that the unsworn testimony of a child under thirteen years required corroboration as a matter of law, and in practice because it was a sexual offence, generated further appeals, as did the question of whether a victim's (often reluctant) mother could be compelled to give evidence in support. In 1911 Benjamin Brown appealed against two separate convictions involving his daughters, Constance and Lily. He was first convicted on 16 June 1910 at Chelmsford Assizes in respect of Constance and sentenced to four years imprisonment. He won his appeal in December that year on the grounds that the jury had not been properly cautioned about how they should accept Constance's uncorroborated evidence. ${ }^{78} \mathrm{He}$ appeared at the same court on 3 February 1911 in respect of Lily, and was also sentenced to four years, but this time the trial judge ensured the jury were forewarned. Brown optimistically tried the same appeal again but this time it was dismissed. Corroboration was shown in the doctor's medical examination that Lily had had frequent intercourse with someone, combined with, somewhat ironically, Brown's voluntary testimony admitting his previous sexual conduct with Constance.

At Stafford Assizes, a man named Leach was convicted for incest on his daughter after his wife had been compelled by the trial judge to give evidence against him. The CCA affirmed the judge's direction ${ }^{79}$ and so he appealed to the House of Lords. ${ }^{80}$ At common law a husband and wife were legally regarded "as one person in the eye of the law"; a wife could only be compelled to give evidence against her husband in a criminal court if this was enshrined in statute or constituted one of the three common law exceptions where the husband was accused of high treason, personal injury to his wife, or forcible abduction followed by marriage. Section 4 of the Criminal Evidence Act 1898 permitted a wife to give evidence if her husband objected, but she could not be compelled against her will. Allowing the appeal, Loreburn and Halsbury (somewhat ironically given his 
involvement in the statute's production) criticised Parliament for failing to clarify the issue in the 1908 Incest Act. Loreburn, no doubt much to Halsbury's chagrin, demanded "What is the meaning of the law as laid down in the 1908 Act ?" 81 Such a clause had been included in the original Bill but was rejected at the Commons Second Reading on the grounds that "the crime was not serious enough to warrant it."

A problematic case in terms of the legal extent of the ban was John Love Elliott, 48 years, a wealthy American mining engineer indicted at Lewes Assizes in March 1914. The Times' report is brief but the fact that "the previous day had been taken up hearing the evidence of his young daughter" suggests a charge of incest. ${ }^{83} \mathrm{~A}$ follow up report a week later that Elliott had been convicted and sentenced to five years imprisonment refers to the daughter as aged twenty, she would therefore have been under sixteen years at the time the offences were committed "on divers dates" between 16 November 1910 until 15 November 1913. That she was not charged with the permitting offence is further confirmation. ${ }^{84}$ The in camera rule only applied to the British press; absurdly, the American press could publish as much information as it could get hold of. The New York Times carried nine reports about the case from arrest to conviction, but its editor was frustrated about "the secrecy surrounding the whole affair." Their London correspondent was rebuffed by Scotland Yard, the East Grinstead police stated that they knew nothing of the case other than confirming that "a meagre account" had appeared in one of the London morning dailies. ${ }^{85}$ On attending the committal hearings the journalist reported back that the "the public press were excluded" from the first day of the trial, the public were "rigidly excluded" and expressed surprise that "even the local newspaper men" were excluded. ${ }^{86}$

The New York Times reports provide more factual information: Elliott, a well-known entrepreneur, had moved to a stately Georgian home near East Grinstead with his two daughters, Doris aged 18 and Florence 17, whose mother had died. In 1907 he had caused a sensation in New York when he acrimoniously divorced his second wife, a renowned opera singer, and taken a third wife. ${ }^{87}$ Elliott came to the attention of Chief Inspector Fowler at Scotland Yard when a neighbour reported comments the daughters had made. Initially, the police were reluctant to make an arrest, but corroborating statements from other neighbours and a servant confirmed their disclosures resulting in Elliott's arrest and first court appearance on 26 November at East Grinstead petty sessions. The preliminary hearings lasted fifteen days producing 325 sheets of foolscap. Elliott was remanded on bail in the sum of $£ 10,000$. On 9 March 1914 he was indicted at Lewes Assizes, the trial lasted six days, 36 witnesses were subpoenaed and 74 exhibits presented. Contrary to Halsbury's concerns, the reportage can hardly be described as sensational, immoral or even euphemistic ; there is no explicit reference to the word "incest" with the charge simply described as a "serious offence". It is testament to the respect the British press had for the law that so little was published, but it is also disconcerting that the censure of such lengthy proceedings involving a man with means was justified as not being in the public interest. In 1918, while giving evidence to the Joint Select Committee on the Criminal Law Amendment Bill, Sir George Riddell of the Newspaper Society pointed out the irony of the law that such "a big case" had been fully reported in the American press but could not be reported domestically. ${ }^{88}$

The use of the wording of "divers dates" in indictments was challenged by James Thompson, charged at Durham Assizes that "on divers days" between February 1909 and 4 October 1910, and between 4 October 1910 and the end of February 1913, he had 
committed incest with his daughter aged under sixteen. Sentenced to four years, Thompson claimed this prejudiced any fair trial as he had been charged with an "indefinite number of offences". The Lord Chief Justice, Rufus Isaacs, confirmed that, "Upon perusal of the evidence the offences had undoubtedly been committed", therefore no substantial miscarriage of justice had occurred. ${ }^{89}$

In another appeal on a technical legal point, Joseph Simmonite, charged with incest at Leeds Assizes for carnally knowing his nine year-old daughter, Harriet Pollard, was instead found guilty of indecent assault and sentenced to twelve months imprisonment. Section 4(3) of the Incest Act permitted the jury to return an alternative verdict of guilty under section 4 CLAA 1885 (carnal knowledge of a girl under thirteen) which in turn allowed a conviction for indecent assault to be substituted (under section 9) where, for example, the evidence was ambiguous about the nature of the penetration. The CCA confirmed that where incest is charged a presumption exists that the accused must also be regarded as indicted under the CLAA $1885 .^{90}$

Occasionally simple sentencing appeals were reported in the press such as a brief four line column of a sentence reduced from ten years to five. ${ }^{91}$ But the law was even unclear as to whether the original sentence, the fact it had been substituted, and the details of the new sentence, could be published. For example, Rufus Isaacs permitted a reduction in the 'excessive' sentence imposed on Thomas Keats at Dorchester Assizes to three years. Isaacs was persuaded by the jury's expression of sympathy for the squalid conditions in which Keats and his family lived, but the report offers no details of the original sentence imposed. Either the judge believed it best not to mention the specific offence and tariff or the reporter felt compelled to censure it..$^{92}$

\section{Turn the Light on Darling}

In 1897 Halsbury controversially appointed one of his acolytes, a little known criminal barrister from the Oxford Circuit, Charles Darling QC to the bench. Darling had not yet secured his reputation as 'an eminent lawyer' and thought that he was "being promoted on political grounds." ${ }^{93}$ Depicted the same year by Spy in Vanity Fair as 'Little Darling' he had first-hand experience of prosecuting physical and sexual assaults against women and children ${ }^{94}$ Darling was regularly listed to try incest cases and on occasion acted on behalf of the Lord Chief Justice, he sat on all of the incest appeal panels, argued at the CCA, including the cases of Thompson and Simmonite above. However, Darling became increasingly frustrated about the in camera rule believing that it had led to public ignorance of the Incest Act and lack of awareness about the nature of the crime..$^{95} \mathrm{In}$ January 1919, he tried two incest cases on the same day, acquitting Walter Abbott and sentencing a man named Duncan to five years. Darling expressed his incredulity that noone apart from the judge and jury knew of the two trials :

I think it would be very much better that these cases should be heard publicly as other cases with regard to rape and carnal knowledge of women....These cases of incest are no more indecent in their details... they are as to the facts and details precisely on the same level...

Seemingly unaware of Halsbury's rationale he added, "How it was that Parliament enacted that these cases must be heard in secret I don't know" surmising it must have been because formerly the ecclesiastical courts heard all cases in camera. Halsbury had been concerned that publicizing incest trials would produce a vicious circle of copycat 
offences and sensational reportage; Darling's view was that the silence meant many accused were ignorant of the law and did not appreciate it was a criminal offence. ${ }^{96} \mathrm{And}$ it was not just those accused that had a limited understanding of the law.

On 6 March, trying yet another case, Darling issued a controversial edict that the in camera rule should exclude all counsel not directly engaged in a particular case so they could watch and learn how to conduct incest proceedings. ${ }^{97}$ He generated considerable confusion initially saying it did not matter whether they were wearing full court robes while observing or not. The following day he was forced to concede that he had meant only barristers in full dress, ingeniously justifying his direction that "it would be easier for the doorkeeper to recognize the right of those to enter who were in robes and that while not engaged in the case as such they could always be called upon in court if necessary, e.g. to act as amicus curiae." As observers they could raise an argument or case not known to the judge, a duty all barristers owed to the court: "after all a barrister learns his role best by sitting in court and watching." 98

Sir Herbert Stephen, barrister, Clerk to the Northern Assizes, Conservative MP and prolific letter writer, who had previously written to The Times in 1918 in support of Justice McArdle at Liverpool Crown Court describing the rule as "unjust and dangerous", 99 now wrote a second letter repeating his concerns. Supporting Darling's proposal he wrote : "I am sorry to trouble you again concerning a discreditable feature of a disagreeable topic", but the instruction in the statute should be interpreted as allowing the judge discretion to "exclude anyone he pleases, not to compel him to exclude everyone." ${ }^{100} \mathrm{~A}$ few days later Darling showed that he was willing to stand his ground and use his discretion when he engaged two observing barristers to defend an unrepresented man accused of incest. ${ }^{101}$ The absurdity of the in camera rule is effectively highlighted in the case of Kingsland which was first heard in a closed court where Darling sentenced Edward Kingsland, a 54 year-old boot repairer, to twelve months imprisonment for nineteen counts of incest with his adult daughter. The following week Darling allowed this incest conviction to be disclosed to convict Kingsland in open court for two counts under the CLAA 1885 between 1906-1907 of having sexual intercourse with his younger daughter when she was under thirteen years. Darling imposed a sentence of ten years for this felony, and another ten years (to run concurrently) for the further offences of incest. Darling expressly points out the incongruity of the press being permitted to report the conviction of the carnal knowledge of a girl under thirteen, but not to publicly acknowledge its incestuous nature. Further, he warned that Kingsland could have been imprisoned for life commenting that "a man might be sent to penal servitude and never appear again", no-one would know what had happened to him except a few persons in court. ${ }^{102}$

Though not falling under the legal definition of incest there were some attempts to prosecute fathers who had molested their wife's child from a previous relationship. Mostly these failed, as not only were they non-consanguineous but if the child had been born out of wedlock the courts would generally refuse to accept any evidence that would confirm their bastardy. ${ }^{103}$ Gerald Dodson, who had married his wife when she was two months pregnant by another man, found himself in an invidious position when indicted some years later before Darling on a charge of incest against his 'adopted' daughter. As she was not his biological child Dodson wanted to prove that his daughter was a bastard to escape conviction for the crime of incest. Darling advised the jury that "if a man were allowed to go into the witness box and swear that a child was not his own, he might commonly be supported by his wife, and a great deal of incest would go unpunished." 104 
The jury found Dodson not guilty but this is another illustration of the legal conundrums that the Act generated and that Darling was forced to rationalise. He strongly believed that the additional shame of the public knowing of a man's immoral acts meant that "publicity is the real penalty... Incest would be less frequent if people knew more about it." 105

A year later Darling was forced to clear the court for a case involving four adult brothers and sisters. Repeating his mantra, "I can say no more about it", underlines his exasperation that incest "would be much less frequent if people knew that, since 1908, it was a crime punishable in the criminal courts." He also sought to distinguish adult sibling incest from child incest advocating that there should be some tolerance: "in nearly all cases the woman consents ... there are not the horrible instances of violence and so on." 106 He affirmed this view in another adult sibling case heard in November 1920 noting that the facts were no more shocking or disgusting than many other sexual offences. The accused had started their relationship before the 1908 Act was passed producing nine children of whom six had died and one suffered a mental disability. ${ }^{107} \mathrm{He}$ immediately wrote to The Times the following day protesting again about the absurdity of the in camera rule and the need for reform. ${ }^{108}$

There is no question that the censure rule was applied inconsistently depending on judicial or magisterial discretion, and was largely respected, if not accepted, by a compliant press. Some judges made occasional references in their opening speeches at the Assizes which were sporadically reported but it is evident that both press and judiciary were uncertain as to their respective positions. ${ }^{109}$ In 1918, a combined Bill to amend the CLAA 1885 proposed an extension of the ban to a range of other sexual offences, permitting judges the discretion to close a court to the public if "desirable in the interests of decency, morality, humanity or justice." ${ }^{110}$ Lord Muir-Mackenzie, the Chair of the Joint Select Committee, strongly opposed the clause. Critical of the minimal press coverage of incest he confirmed, "I do not think criminal cases are indecently or suggestively reported in newspapers." ${ }^{111}$ His assertion was supported by Sir Herbert Stephen, also called to give evidence, who made it clear that the press do not publish "anything licentious in relation to cases involving young girls", reiterating his view that all such cases should be heard in public. ${ }^{112}$ Sir George Riddell reported that the London and Provincial Press conference had passed resolutions casting "grave misapprehension" on the clause as it was unnecessary and undermined the open administration of justice and press responsibility to report matters of significant public interest. ${ }^{113}$

The press continued to push their cause. In October 1919, representatives of the Institute of Journalists and National Union of Journalists campaigned outside North London Police court where a case was listed. They claimed that some magistrates did not exclude the press, and while they would not wish to publish explicit details, they should be permitted to report cases as a matter of principle. ${ }^{114}$ In 1921, Mr Mead, the magistrate at Marlborough Street Police court made a point of asking the press to leave to demonstrate his frustration that it was an anomalous provision "severely criticized in high places." 115

By 1922, even the newly appointed Lord Chief Justice, Hewart, acknowledged that he did not know how to apply section 5 of the 1908 Act regarding an appeal at the CCA involving a nineteen year-old sister and her seventeen year-old brother whose sentences had been reduced to six months from twelve months and fifteen months respectively. The defence counsel offered no objection to the CCA hearing the case in public but Hewart determined that the rule not only applied to the trial proceedings but should now apply to appeal 
hearings as well, though he did permit the law reporters to stay. ${ }^{116}$ Thus fifteen years after its enactment the in camera rule was still causing considerable judicial uncertainty and confusion.

Meanwhile, during the closing debates of the CLA Bill in 1921, the Lord Chancellor, Lord Birkenhead, unequivocally proposed that the rule be repealed raising an even more important point, that as acquittals could not be announced no-one would know if an accused had been found not guilty. The Earl Russell finally acknowledged that it was no longer desirable to maintain the rule and the amendment was agreed. ${ }^{117}$ However, a last minute ambuscade from the Commons to reform section 5, rather than repeal it, threatened to undermine the whole Bill. The Bishop of Norwich pressed the Lords to allow judges a more limited discretion to direct that a particular case be held in camera in exceptional cases. Birkenhead was adamant: "The right rev Prelate is in error, in my opinion, when he suggests that the whole subject of trials in camera need reconsideration. It needs no reconsideration in my opinion." Alluding to some trial judges - presumably Darling - who had sought to get the section repealed, he reiterated that "In no circumstances could I agree to such a proposal." ${ }^{118}$ Lord Phillimore, who also had experience of trying incest cases, supported the amendment justifying it as a qualification to the existing law rather than a last minute ambuscade. Earl Beauchamp admitted that as Lord Steward of the Household under Asquith he had been responsible for persuading the Government to accept Russell's proposal in 1908 and now acknowledged it was a mistake and one that he wanted to see repealed. ${ }^{119}$ As a result the motion was rejected and section 5 was finally replaced by section 5 CLAA 1922, but public confusion about whether incest was actually a crime remained, as illustrated by Justice Roche at Northampton Assizes in 1925 who said it would not "outrage anybody's feelings of indecency if they called a spade a spade" as there was a "stratum in society that did not know incest was a crime." 120

\section{Conclusion}

50 It initially appears that on the face of the historical record there is limited source material to analyse regarding the immediate prosecution of incest following the 1908 Punishment of Incest Act. The in camera rule ensuring cases were heard in closed court not only restricted the publication of information about such trials but reinforced the incest 'taboo' prolonging public ignorance that it was a crime, allowing some offenders to claim lack of knowledge and preventing, or at least limiting, informed public discourse. Ironically, as demonstrated here, at least the existence of the controversial in camera rule generated an amount of newspaper reportage and judicial commentary and possibly more than if it had never been introduced in the first place. But despite the repeal of the ban in 1922 its ramifications endured and no substantive changes were made to the law. The incest provisions in sections 1 and 2 of the 1908 Act were simply renumbered as sections 10 and 11 respectively in the consolidating Sexual Offences Act 1956 replacing 'carnal knowledge' with the more modern term of 'sexual intercourse'. The two offences had become seriously outdated and the word 'incest' was finally expunged from the law when the Sexual Offences Act 2003 replaced it with the term 'familial sexual abuse' to reflect the looser structure of modern families. The statute introduced a new suite of offences to deal with child sexual exploitation placing more emphasis on those who abuse their position of trust and removing the stigmatization of 'incest' from the law and extending liability to aunts, uncles, cousins, step-parents, adoptive parents, fosterers and 
other full-time carers. ${ }^{121}$ The Press Complaints Commission Code of Practice 2003 also prohibited the word 'incest' being used where a child victim might be identified. This supports Mitterauer's assertion that "incest rules can long outlive the social conditions which produced them ...[and that]... incest prohibitions as cultural norms, never seem to have a simple explanation." 122

\section{BIBLIOGRAPHY}

\section{References}

Bailey, V., and Blackburn, S., 'The punishment of Incest Act 1908 : A case study of law creation', Criminal Law Review, 1979, p. 708-718.

Bailey, V., and McCabe, S., 'Reforming the law of incest', Criminal Law Review, 1979, p. 749-764.

Bates, V., Sexual forensics in Victorian and Edwardian England : Age, Crime and Consent in the Courts, Basingstoke, Palgrave Macmillan, 2016.

Behlmer, G., Child abuse and moral reform in England 1870-1908, Stanford, Stanford University Press, 1982.

Bell, V., Interrogating incest, feminism, Foucault and the law, London, Routledge, 1993.

Blaikie, A., 'Monsters within : child abuse in modern English history', in (Blaikie, A. Ed.) After Beckford ? essays on themes related to child abuse, Egham, Department of Social Policy, 1987.

Bingham, A., and Settle, L., 'Scandals and silences : the British press and child sexual abuse', History and Policy, 4 August 2015.

Bingham A., Delap, L., Jackson L., and Settle L., 'Historical child sexual abuse in England and Wales : the role of historians', History of Education, 2016, 45(4), p. 411-429.

Booth, W., In darkest England and the way out, London, Funk and Wagnalls, 1890.

Brown, A. and Barrett, D., Knowledge of evil : child prostitution and sexual abuse in twentieth-century England, Abingdon, Willan, 2002.

Clark, A., Women's silence men's violence : sexual assault in England 1770-1845, London, Pandora, 1987. Cohen, D., Family secrets : Shame and privacy in modern Britain, Oxford, Oxford University Press, 2013.

Conley, C., The unwritten law : criminal justice in Victorian Kent, Oxford, Oxford University Press, 1991.

Criminal Law Revision Committee, Sexual offences, $15^{\text {th }}$ Report, Cmnd.9213, London, HMSO, 1984.

D'Cruze, S., Crimes of outrage : sex, violence and Victorian working women, London, University College London Press, 1998.

Davidoff, L., Doolittle, M., Fink J., and Holden K., The family story : blood, contract and intimacy in modern England, 1840-1960, London, Longmans, 1999.

Finkelhor, D., Sourcebook on child sexual abuse, Newbury Park CA, Sage, 1986. 
Finkelhor, D., Nursery Crimes, Newbury Park CA, Sage, 1988.

Gibbens, T., 'Incest and sexual abuse of children', in Hopkins, J., (Ed.) Perspectives on rape and sexual assault, London, Harper and Row, 1984.

Hendrick, H., Child welfare : England 1872-1989, London, Routledge, 1994.

Hendrick, H., Child welfare : historical dimensions contemporary debate, Bristol, Policy 2003.

Home Office, Prosecution of Offences Act 1879, 1884 and 1908 returns, Paper 215, London, HMSO, 1910.

Home Office, Prosecution of Offences Act 1879, 1884 and 1908 returns, Paper 217, London, HMSO, 1911.

Home Office, Judicial statistics, England Wales, 1910, part 1 criminal statistics Cd.671, London, HMSO, 1912.

Home Office, Judicial statistics, England Wales, 1919, part 1 criminal statistics Cmd.1424, London, HMSO, 1921.

Home Office, Report of departmental committee on sexual offences against young persons, 1924-1925, Cmd.2561 London, HMSO, 1925.

Home Office Communication Directorate, Setting the boundaries, London, July 2000.

Houghton, W., The Victorian frame of mind, New Haven, Yale University Press, 1974.

Hoyles, M., Changing childhood, London, Writers \& Readers Publishing Group, 1979.

Ingram, M., Church courts, sex and marriage in England 1570-1640, Cambridge, Cambridge University Press, 1987.

Jackson, L., Child sexual abuse in Victorian England, London, Routledge, 2000.

Jeffreys, S., The spinster and her enemies : feminism and sexuality 1880-1930, Melbourne, Spinifex, 1997.

Joint Select Committee of the House of Lords and House of Commons, Report on the Criminal Law Amendment Bill and Sexual Offences Bill, London, HMSO, 19 November 1918.

Keating, P., (ed.) Into unknown England 1866-1913 : Selections from the social explorers, Glasgow, Fontana Collins, 1978.

La Fontaine, J., 'Child sexual abuse and the incest taboo', Man 1988, 23(1), p. 1-18.

Mitterauer, M., 'The customs of the Magians : The problem of incest in historical societies', in Porter, R., and Teich, M., (Eds.) Sexual knowledge : sexual science the history of attitudes towards sexuality, Cambridge, Cambridge University Press, 1994.

Morris, P., 'Incest or survival strategy? Plebeian marriage within the prohibited degree in Somerset 1730-1835', in Fout, J., (Ed.) Forbidden history, the state, society and the regulation of sexuality in Modern Europe, Chicago, University of Chicago, 1992.

Mort, F., Dangerous sexualities : medico-moral politics in England since 1830, London, Routledge, 2000.

Morton, J., ‘The Incest Act 1908 : was it ever relevant ?' New Law Journal, 1988(138), pp. 59-60.

Olafson, E., Corwin D., and Summit, R., 'Modern history of child sexual abuse awareness : cycles of discovery and suppression', Child Abuse and Neglect, 1993(17), p. 7-24.

Pollock, L., Forgotten children : parent child relations from 1500-1900, Cambridge : Cambridge University Press, 1983.

Rowbotham, J., Stevenson, K., and Pegg, S., Crime news in modern Britain : press reporting and responsibility 1850-2010, Basingstoke, Palgrave Macmillan, 2013. 
Royal Commission, First Report on the Housing of the Working Classes, Cd. 4402, 1884-85.

Sellar, W., 'Marriage, divorce and the forbidden degrees : Canon Law and Scots Law', in Osbrough, W., (Ed.) Explorations in law and history : Irish Legal History Society discourses 1988-1994, Dublin, Irish Academic Press, 1995.

Smart, C., 'Reconsidering the recent history of child sexual abuse, 1910-1960', Journal of Social Policy, 2000, 29 (1), p. 55-71.

Stevenson, K., 'The respectability imperative : a golden rule in cases of sexual assault ?' in Inkster, I., (Ed.), Golden age ? Britain 1850-1870, Aldershot, Ashgate, 2000, p. 237-248.

Stevenson, K., 'Unearthing the realities of rape : utilising Victorian newspaper reportage to fill in the contextual gaps', Liverpool Law Review, 2007, 28(3), p. 405-423.

Stevenson, K., 'Outrageous Violations : enabling students to interpret nineteenth century newspaper reports of sexual assault and rape', Law Crime and History, 2014(1), pp. 36-61

Stevenson, K., "“Not just the ideas of a few enthusiasts" : early twentieth century legal activism and reformation of the age of sexual consent', Cultural and Social History, (accepted for publication, forthcoming 2017).

Walker-Smith, D., The life of Lord Darling, London, Cassell, 1938.

Weeks, J., Sex, politics and society, $2^{\text {nd }}$ ed. London, Longman, 1989.

Wiener, M., Men of blood, violence, manliness and criminal justice in Victorian England, Cambridge, Cambridge University Press, 2004.

Wohl, A., 'Sex and the single room : incest among the Victorian working classes', in (same Ed.) The Victorian family, London, CroomHelm, 1978.

Wolfram , S., 'Eugenics and the Punishment of Incest Act 1908', Criminal Law Review 1983, p. 308-316.

Wolfram , S., In-laws and out-laws : kinship and marriage in England, Beckenham, Croom-Helm, 1987.

\section{NOTES}

1. https://www.csa-inquiry.independent.gov.uk/

2. Jackson (2000) ; Finkelhor $(1986$; 1988). Brown and Barrett (2002) does cover the period, but its focus is primarily on child prostitution.

3. Smart (2000).

4. Bingham et.al (2016).

5. Bingham \& Settle (2015).

6. Behlmer (1982); Hendrick (1994; 2003); Wohl, (1978).

7. Jeffreys (1997).

8. Bailey and Blackburn (1979); Bailey and McCabe (1979).

9. Bell (1993, ch.5).

10. Wolfram $(1983 ; 1987$, ch.7).

11. Bates (2016).

12. Olafson et al. (1993, p. 8).

13. La Fontaine (1988, p. 3). 
14. Mitterauer surmises that there are two aspects to the incest taboo and aversion to incestuous relationships: one based on the biological potential for 'inbreeding' and other on the social proximity of individuals (1994, pp. 233-234).

15. Davidoff et. al. (1999, p. 245).

16. Cohen (2013).

17. See Clark (1987); Jackson (2000); Wiener (2004). D'Cruze (1998) usefully highlights how the correlation of Justices Petty Sessions Minutes with newspaper reportage can provide more detailed narratives.

18. See Stevenson (2007) ; Stevenson (2014). After 1914, professional journalists took over the reportage from the courts, but until the 1950s were still strongly influenced by the earlier involvement of barrister reporters.

19. Rowbotham, Stevenson and Pegg, (2013), ch.4.

20. For example in 1910 while the number of persons tried on indictment and summarily for violent offences fell, for sexual offences they rose from 1,158 to 1,435 , reflecting both changes in the law and more robust prosecutorial practices Home Office (1912, p. 10).

21. See 18th chapter of Leviticus. Transgressions fell under the jurisdiction of the Canon or 'bawdy' courts but prosecutions were comparatively rare see Ingram (1987, p. 245-47).

22. The death penalty was rarely imposed (Sellar, 1995, p. 77), but was not abolished until the Criminal Procedure (Scotland) Act 1887.

23. During the interregnum, the Commonwealth Act 1650 made incestuous marriage a felony punishable by death, but after 1661 jurisdiction, according to Blackstone, reverted back to the "feeble coercion of the spiritual court, according to the rule of canon law". Cited in Bailey and Blackburn (1979, p. 708).

24. Wolfram (1987, pp. 30-40) ; Morris (1992, p. 140). The Act was not repealed until the Deceased Wife's Sister's Marriage Act 1907 which, as reflected in the contemporaneous incest Bill debates, marked a significant shift from affinal to consanguineous prohibitions, see Wolfram (1987, p. 141)

25. Clark (1987, p. 18, 101-103).

26. Ibid, p. 101-103) ; Conley (1991, p. 121).

27. D'Cruze (1998, p. 169).

28. Conley (1991, p. 121) cites a father acquitted on the grounds of consent where he admitted having sexual intercourse with his daughter for six years, since she was aged eleven.

29. Excluding 1788-1790, Pollock (1983, p. 93). In fact one of the most regular themes in Victorian pornography was incest, but it was of limited or acknowledged public circulation as it was printed privately and accordingly expensive, see 'Sport among the She-Noodles', The Pearl, 4, 1879 ; The Romance of Lust, London, 1873.

30. The Times, 12 March $1855 ; 19$ August 1858.

31. Clark (1987, p. 103).

32. D'Cruze (1998); Stevenson (2000).

33. Houghton (1974, p. 395).

34. Hendrick (2003, p. 59).

35. Wohl (1978, p. 200-201).

36. Hendrick (1994, ch.1).

37. Hoyles (1979, p. 96).

38. Jackson (2000, p. 96).

39. The Times, 2 October 1852.

40. Weeks (1989, p. 31).

41. Cited on NSPCC website http://www.nspcc.org.uk/what-we-do/about-the-nspcc/history-ofNSPCC/history-of-the-nspcc_wda72240.html

42. Booth (1890, p. 65). 
43. Cited in Blaikie (1987, p. 6) and see Wohl for a detailed account of its existence amongst the poor.

44. Royal Commission (1884-1885), p. 13.

45. Jackson (2000, p. 49).

46. Jeffreys, (1997, p. 17-18).

47. Reproduced in Keating (1978).

48. Behlmer (1982, p. 70).

49. See Jeffreys (1997, ch.3).

50. See Stevenson (forthcoming 2017).

51. Mort (2000, p. 105).

52. See Hendrick, (2003, p. 60), Mort (2000, p. 105).

53. PP, HL, 27 March 1903, cols.407-408.

54. The state was only just beginning to embrace the concept of, and its responsibility for, regulating unlawful conduct by criminalization, see Mort (2000).

55. PP, HC, 26 June 1903, col.284.

56. Bell, (1993, ch.5; p. 149).

57. PP, HL, 16 July 1903, cols.820-824.

58. Ibid, col.822.

59. Wolfram (1987, p. 138 \& 142).

60. PP, House of Lords, 2 December 1908, Incest Bill 2nd Reading, col.1408.

61. Hendrick (1994, p. 67).

62. Wolfram (1987, p. 43).

63. La Fontaine (1988, p. 6).

64. Home Office (1925, p. 13-14)

65. Gibbens (1984, p. 18-20).

66. Criminal Law Revision Committee (1984); Wolfram (1987, p. 44).

67. Morton, (1988).

68. Home Office Communication Directorate (2000, para.5.2.3).

69. Specifically recommended in the 1925 Departmental Report, Home Office (1925, p. 6).

70. Home Office (1910, p. 14).

71. Home Office (1911, p. 12)

72. Judicial Statistics (1912, p. 10).

73. Jeffreys (1997, p. 39).

74. The CCA abolished the Court for Crown Cases Reserved (established in 1848). Decisions could be appealed to the House of Lords by prosecution or defence with a certificate of leave from the Attorney General provided it was a legal issue of exceptional public importance.

75. $R v$ Henry Hedges (1910) 3 Cr App R 262.

76. The Times, 17 January 1911.

77. DPP $v$ Ball and Ball (1910) 22 Cox CC 366.

78. $R v$ Benjamin Brown (1911) 6 Cr App R 24.

79. The Times, 21 December 1911.

80. Leach $v$ DPP (1912) 22 Cox CC 721.

81. Ibid at 723 .

82. Clause 4 ; its removal was proposed by Mr Rawlinson MP and accepted, PP, House of Commons, 26 June 1908, col.290.

83. The Times, 10 March 1914.

84. The Times, 16 March 1914.

85. New York Times, 23 November 1913.

86. New York Times, 23 \& 27 November 1913.

87. New York Times, 22 November 1913. 
88. Joint Select Committee (1918, p. 127).

89. $R v$ Thompson (1913) 24 Cox CC 43 ; The Times 31 July, 20 December 1913 note that The Times report offers more detail than the official report.

90. $R v$ Simmonite (1916) 25 Cox CC 544.

91. $R v$ Cooper, The Times, 13 May 1914.

92. The Times, 19 November 1913.

93. Walker-Smith (1938, p. 92).

94. Ibid (p. 72).

95. Surprisingly, there is no mention of any such cases or concerns in his biography by WalkerSmith (1938).

96. The Times, 11 January 1919.

97. The Times, 7 March 1919.

98. The Times, 8 March 1919.

99. The Times, 8 February 1918.

100. The Times, 8 March 1919.

101. The Times, 12 March 1919.

102. The Times, 12 March 1919.

103. See $R v$ Carmichael (1939) 31 Cox CC $409 ; R v$ Hemmings (1939) 31 Cox CC 240.

104. The Times, 20 June 1919.

105. The Times, 5 May 1920 cited by Lord Burnham in report of parliamentary debates about the Matrimonial Causes Bill.

106. The Times, 20 March 1920.

107. The Times, 19 November 1920.

108. The Times, 20 November 1920.

109. For example two cases of incest at the Central Criminal Court are mentioned at the September Sessions in 1911 see The Times, 6 September 1911 and a further two cases in September 1913, The Times, 3 September 1913.

110. Clause 9.

111. Joint Select Committee (1918, p. 7).

112. Ibid p. 78.

113. Ibid. p. 126.

114. The Times, 15 October 1919.

115. The Times, 17 October 1921.

116. The Times, 9 May 1922.

117. PP, House of Lords 15 March 1921, cols.572-573.

118. PP, House of Lords 15 August 1921, cols.579-580.

119. Ibid, col.581.

120. The Times, 6 Jun 1925.

121. Sections 25-29.

122. Mitterauer (1994, p. 247). 


\section{ABSTRACTS}

Proposals to criminalize incest in England and Wales, which was formalised in several the Incest Bills from 1899 to 1907, met considerable resistance from the Lord Chancellor who thought the subject too repulsive for public debate. Concerned that the issue would be greatly magnified if such crimes were prosecuted through the criminal courts he believed that the press could not be trusted to report them responsibly. Ultimately, two amendments ensured that the Punishment of Incest Act 1908 was passed, which ruled that the Director of Public Prosecutions must approve any prosecution and that such trials must be held in camera. This article suggests that as cases started to be prosecuted in the courts, it was not only the press but also judges and magistrates who expressed disquiet about such censure. The article also offers some commentary on the difficulties of accessing historical sources in relation to the historiography of incest.

Les propositions de criminalisation de l'inceste en Angleterre et au Pays de Galles, formalisées dans plusieurs propositions de lois entre 1899 et 1907, se heurtèrent à une résistance considérable de la part du Lord Chancellier qui estimait la question trop répugnante pour être publiquement débattue. Préoccupé par le fait que des procès criminels grossiraient grandement ce problème, il était persuadé qu'on ne pouvait se fier à la presse pour en rendre compte de manière responsable. Finalement, la loi Punishment of Incest Act de 1908 fut votée grâce à deux amendements soumettant toute poursuite à l'accord du Directeur du ministère public et tout procès au huis-clos. L'article avance qu'à mesure que les procès se multiplièrent, la presse ne fut pas la seule à s'inquiéter de cette censure, mais que ce fut également le cas des juges. L'article s'interroge aussi sur les difficultés d'accès des sources historiques dans le domaine de l'inceste.

\section{AUTHOR}

\section{KIM STEVENSON}

Professor of Socio-Legal History at Plymouth University and is co-founder and director of " SOLON : Interdisciplinary Studies in Law, Crime and History' and co-editor 'Routledge SOLON : Explorations in the Histories of Crime and Criminal Justice'. Citation in the title is by Per Lord Halsbury, Lord Chancellor, during debates on the Incest Bill, Parliamentary Papers (PP), House of Lords, 16 July 1903, cols.820-824. - kim.stevenson@plymouth.ac.uk 